\title{
Taxonomic and Phylogenetic study of Termitomyces entolomoides in western Assam
}

\author{
M. Rava ${ }^{1}$, R. Ali $^{2}$, S. Das ${ }^{3 *}$ \\ ${ }^{1,2,3}$ Department of Biotechnology, Bodoland University Kokrajhar, Assam, India \\ *Corresponding author: sandeep_dna2003@yahoo.co.in, Tel: 09435701585
}

Available online at: www.isroset.org

Received: 28/Jan/2019, Accepted: 10/Feb/2019, Online: 28/Feb/2019

\begin{abstract}
Termitomyces genus is paleotropical in nature and is known for its obligate symbiotic association with termites belonging to Macrotermitinae. The Termitomyces sample was collected during the monsoon and post monsoon period (AprilOctober). The basidiocarp was oven dried and used for the macro-morphological and micro-morphological studies. Identification of fungi using morphological characters is very complicated and error prone. Furthermore, internal transcribed spacer (ITS) region 1, 5.8S rRNA gene and ITS 2 region was amplified using ITS 1 and ITS 4 primer pairs. The amplicon of 600 bps was sequenced and subjected to Phylogenetic analysis in MEGA X sowftware package. Newly obtained sequence and 19 sequences of Termitomyces from NCBI GenBank were aligned using MAFFT. Phylogenetic tree was constructed using Maximum Likelihood method with bootstrap values of $\leq 70 \%$. The morphological characters and molecular data indicate the studied sample as Termitomyces entolomoides. Phylogenetic relationship of the studied species with 19 Asian Termitomyces species obtained from NCBI GenBank is established and is clearly monophyletic.
\end{abstract}

Keywords-Termitomyces, identification, ITS region, molecular phylogeny.

\section{INTRODUCTION}

The paleotropical genus Termitomyces of Lyophyllaceae family lives in obligate symbiotic relationships with termites belonging to the subfamily Macrotermitinae (Isoptera). The termites provide the ambient micro climatic condition suitable for the growth and propagation of the fungi and the later provide enzymatic supplement to aid digestion of the divergent termite food [1]. The fungal combs are made up of partially digested plant material to support the growth of Termitomyces and to prevent the comb's colonization by competitive fungi [2]. The detailed study of the genus Termitomyces was first described from Central Africa in 1977 and India in 1979 [3]. Several other taxa of Termitomyces have been documented and described by many authors including Heim 1951, 1952, 1958, 1977; Otieno 1964; Pegler 1977; Natarajan 1979; Piearce 1987; Van der Vanhaecke 1994; Turnbull and Watling 1999; Mossebo 2000, 2002; Mossebo et. al. 2002, 2006, 2009, 2011; Wei et. al. 2004; Tang et. al. 2005, 2006 [4,5]. Termitomyces is one of the most popular edible mushrooms of North Eastern Region of India, highly preferred by the ethnic tribal group viz. Bodo, Rabha, Garo, Kochari, Lalung etc.
Approximately 30 Termitomyces species are known [6] all together they covers a wide range of morphological range, includes Termitomyces titanicus with a cap diameter of $1 \mathrm{~m}$ making it the largest fruiting body of gilled mushroom and Termitomyces microcarpus which rarely exceeds $2 \mathrm{~cm}$ in diameter. The specific characteristics of Termitonyces mushrooms are the pinkinsh spores, long subterranean pseudorhiza and termite association. Most of the species have the 'perforatorium', a knob like structure also called as umbo, which play an important role during penetration of the soil [7].

Identification and classification of Termitomyces species based on morphological and physiological characteristics is difficult. Often, the morphological characteristics do not distinguish different species of fungus [2]. Therefore, molecular techniques are required to identify and classify the species to a better extent. Ribosomal DNA (rDNA) studies provide a means for analyzing phylogenetic relationships over a wide range of taxonomic levels [8]. The internal transcribed spacer (ITS) region and intergenic spacer (IGS) region of the nuclear DNA repeat units evolve fastest and may vary among the species within a genus or among populations [9]. The ITS region of rRNA consists of $18 \mathrm{~S}$, 
ITS1, 5.8S, ITS2 and 28S genes. ITS1 is located between $18 \mathrm{~S}$ and 5.8S rRNA genes, whereas ITS2 is located between $5.8 \mathrm{~S}$ and $28 \mathrm{~S}$ rRNA genes [9]. As the ITS region shows more divergence than their flanking regions they are routinely used to distinguish related species and to infer phylogenetic relationships among populations [2].

Occurrence of 19 species of Termitomyces has been recorded in six states of the Western Ghats and on the west coast of India [4]. Literature cited reveals occurrence of 8 species of Termitomyces from the North East India $[10,11,12,13,14]$. The present study confirms the occurrence of $T$. entolomoides in this zone, its morphological study and phylogenetic relationship with other species of Termitomyces of Asian origin.

The rest of the paper is organized as follows, Section I contains the Introduction of the genus Termitomyces, related Taxonomic and molecular work. Section II contains the methodology used to carry out the present study i.e., sampling, morphological studies and molecular phylogeny study. Section III describes the results and discussions with hand drawings, images of microscopic plates and phylogenetic tree. Section IV contains the Conclusion of the study with future scopes.

\section{MATERIALS AND METHODS}

\section{Sample Collection and Taxonomic Study}

The sample was collected from Kokrajhar District of western Assam during monsoon and post monsoon period. The sample was oven dried at $40^{\circ} \mathrm{C}$ and used for the subsequent study. Different parts of basidiome viz. cutis, gills, stipe, pileus were studied under the microscope. The sections were manually made by hands using razor blade. Macro and micro morphological characters were studied for the collected Termitomyces species. Habitat notes, general characters of pileus, lamellae, stipe were recorded along with field photographs (Canon 600D and 800D, Canon Macro lens 100 $\mathrm{mm}$ with image stabiliser and Ultrasonic motor and CMOS sensor). Methuen Handbook of color by Kornerup and Wanscher [15] was referred for color code. Microscopic study was carried out using $5 \% \mathrm{KOH}$, Congo red and Phloxin in biological microscope Olympus CX43, eyepiece attached with drawing tube. Measurement of basidiospores were based on 20 readings and the same was done with basidia, cheilocystidia and pleurocystidia (10 readings), at 1000x magnification. Sizes were shown as $\mathrm{MIN}_{\mathrm{L}}-\mathrm{M}_{\mathrm{L}^{-}}$ $\operatorname{MAX}_{\mathrm{L}} \quad \mathrm{X} \quad \mathrm{MIN}_{\mathrm{W}}-\mathrm{M}_{\mathrm{W}}-\mathrm{MAX}_{\mathrm{W}}$ where, $\mathrm{MIN}_{\mathrm{L}}=$ measurement for minimum length, $\mathrm{MAX}_{\mathrm{L}}=$ measurement for maximum length, $\mathrm{M}_{\mathrm{L}}=$ arithmetic mean of length and $\mathrm{MIN}_{\mathrm{W}}$ $=$ measurement for minimum width, $\mathrm{MAX}_{\mathrm{W}}=$ measurement for maximum width, $\mathrm{M}_{\mathrm{W}}=$ arithmetic mean of width. For basidiospores, $\mathrm{Q}$ value was given $(\mathrm{Q}$ means Quotient =
Lenght/Width) where, $\mathrm{Q}=$ mean quotient value. The measurement of the hyphae were shown as $\mathrm{MIN}_{\mathrm{w}}-\mathrm{MAX}_{\mathrm{w}}$ and were based on 10 readings.

\section{DNA isolation and PCR}

DNA isolation was done by CTAB/ Chloroform-Isoamyl alcohol method [16]. ITS region was amplified using ITS 1 (5'-TCCGTAGGTGAACCTGCGG-3') and ITS 4 (5'TCCTCCGCTTATTGATATGC-3') primers [9]. The extracted DNA was used for PCR (Polymerase Chain Reaction) amplification in thermal cycler (Applied Biosystems), which was performed in $25 \mu \mathrm{l}$ reaction volume containing $120 \mathrm{ng}$ of genomic DNA, 10X PCR buffer, 10 picomole of each primer, $2.5 \mathrm{mM}$ each dNTPs and $1 \mathrm{U}$ of Taq DNA polymerase (Invitrogen), nuclease free water was added to make up the final reaction volume. Cycling conditions were - initial denaturation at $94^{\circ} \mathrm{C}$ for 7 minutes, denaturation at $94^{\circ} \mathrm{C}$ for 30 seconds, annealing at $55^{\circ} \mathrm{C}$ for 2 minutes, extension at $72^{\circ} \mathrm{C}$ for 2 minutes, final extension at $72^{\circ} \mathrm{C}$ for 10 minutes and hold at $4^{\circ} \mathrm{C}$. The quality of PCR reaction was examined using $2 \%$ Agarose gel, bands were visualised in UV-base Gel Documentation Unit (Life Technologies) after staining with Ethidium Bromide.

\section{DNA Sequencing and Alignment}

The PCR product was subjected to Sanger sequencing using DNA Sequencer model ABI3730XL-15104-028 (Applied Biosystems) with Sequence Scanner Software 2 v2.0. The newly obtained sequence and sequences obtained from GenBank (Table 1) were aligned and optimized in MAFFT version 7 (https://mafft.cbrc.jp).

\section{Model testing and Phylogenetic Analysis}

To estimate the best fit model for the present dataset, likelihood scores and BIC calculations were calculated in JModeltest [17]. Phylogenetic analyses were performed in MEGA X software package [18]. The phylogenetic tree was constructed by Maximum Likelihood method using TamuraNei model with discrete Gamma distribution rate of variation. To examine the support of interior branch and for the validity of the analysis Bootstrap tests of 1000 replications were conducted. Codon positions included $1^{\text {st }}+$ $2^{\text {nd }}+3^{\text {rd }}+$ non-coding. The evolutionary distances were computed using Maximum Composite Likelihood method. Branches with support value lower than $70 \%$ were collapsed; those above $70 \%$ were supported. 
$\underline{\text { Table } 1}$

\begin{tabular}{|c|c|c|c|}
\hline SI no & Name of Species & $\begin{array}{c}\text { Country of } \\
\text { origin }\end{array}$ & $\begin{array}{c}\text { GenBank } \\
\text { Accession no. }\end{array}$ \\
\hline 1 & Lyophyllum semitale & Sweden & HM572552 \\
\hline 2 & Lyophyllum decastes & Sweden & HM572548 \\
\hline 3 & Termtomyces fuliginosus & Thailand & LC068788 \\
\hline 4 & Termitomyces eurrhizus & China & KJ620056 \\
\hline 5 & Termitomyces eurrhizus & India & KY243929 \\
\hline 6 & Termitomyces microcarpus & India & MH542622 \\
\hline 7 & Termitomyces microcarpus & Thailand & HM230661 \\
\hline 8 & Termitomyces microcarpus & Sri Lanka & KP780436 \\
\hline 9 & Termitomyces heimii & India & JQ928938 \\
\hline 10 & Termitomyces clypeatus & Thailand & HQ702552 \\
\hline 11 & Termitomyces clypeatus & Thailand & FJ147329 \\
\hline 12 & Termitomyces intermedius & China & MF488973 \\
\hline 13 & Termitomyces intermedius & China & MF488972 \\
\hline 14 & Termitomyces radicatus & Thailand & LC068787 \\
\hline 15 & Termitomyces radicatus & Thailand & HM230660 \\
\hline 16 & Termitomyces bulborhizus & Thailand & HM230663 \\
\hline 17 & Termitomyces heimii & Malaysia & EU443836 \\
\hline 18 & Termitomyces aurantiacus & Malaysia & GU594650 \\
\hline 19 & Termitomyces aurantiacus & China & JQ228252 \\
\hline
\end{tabular}

\section{RESULTS AND DISCUSSION}

\section{Taxonomic study}

\section{Termitomyces entolomoides \\ Chapignons (Paris): 52 (1977) [Index Fungorum accessed} on $17^{\text {th }}$ September 2018]

Habitat: on soil, scattered, pleasant odour, edible

Description: Pileus $5 \mathrm{~cm}$, initialy conical, later expanding to plano convex with a prominent obtuse conical perforatorium, surface brown (5E4) at the centre, fading towards the edge to orange grey (5B2), moist, smooth, bluish tints at the centre surrounding the perforatorium, margin wavy, smooth and rimose. Lamellae free, close $\sim 21 / \mathrm{cm}$, consistency brittle, surface white (1B1) to pale pink, smooth edge. Stipe 5-6 x $1.07-2 \mathrm{~cm}$ above soil, surface pastel grey (1C1), central, fusiform, solid, fibrous. Pseudorhiza 5- $10 \mathrm{~cm}$ long, surface yellowish grey (4B3), tapered downwards. Annulus absent. Spore deposit pale pink. Basidiospores 3.7-4.83-5.69 × 2.53.5-4.9 $\mu \mathrm{m}, \mathrm{Q}=1.4$, ellipsoidal, hyaline, thick walled. Basidia 18.93-21.94-24.38 x 5.71-6.74-7.6 $\mu \mathrm{m}$, clavate, sub hyaline, tetrasporate. Pleurocystidia 18.87-23.71-46.07 x 8.44-12.63-33.10 $\mu \mathrm{m}$, scattered, thin walled, sub hyaline. Cheilocystidia 14.71-26.39-34.02 x 9.33-12.16-16.9 $\mu \mathrm{m}$, clavate to fusiform, sub hyaline, thin walled. Hymenophoral trama regular, sub hyaline, composed of 4-10.25 $\mu \mathrm{m}$ wide hyphae, septate, presence of oleiloferous hyphae 4.21-5.75 $\mu \mathrm{m}$ wide. Pileipellis surface consist of repent and radial parallel hyphae, 2.6-4.7 $\mu \mathrm{m}$ wide, septate, thin walled, sub hyaline, no clamp connections. [Fig. $1 \& 2$ ].

Samples examined: INDIA, Department of Biotechnology, Bodoland University, Kokrajhar, Assam, May 2016, (BUMR07). Collected from Sal forest near Magurmari $\left(26^{\circ} 40^{\prime} 74^{\prime \prime} \mathrm{N}, 90^{\circ} 23^{\prime} \mathrm{E}\right)$.

T. entolomoides R. Heim is easily recognized by the medium sized dark colour pileus with bluish tints and swollen stipe at the base. It is the second most abundant mushroom found in the western Assam. In India, it has been reported from Goa [4] and Kerela [19,20].

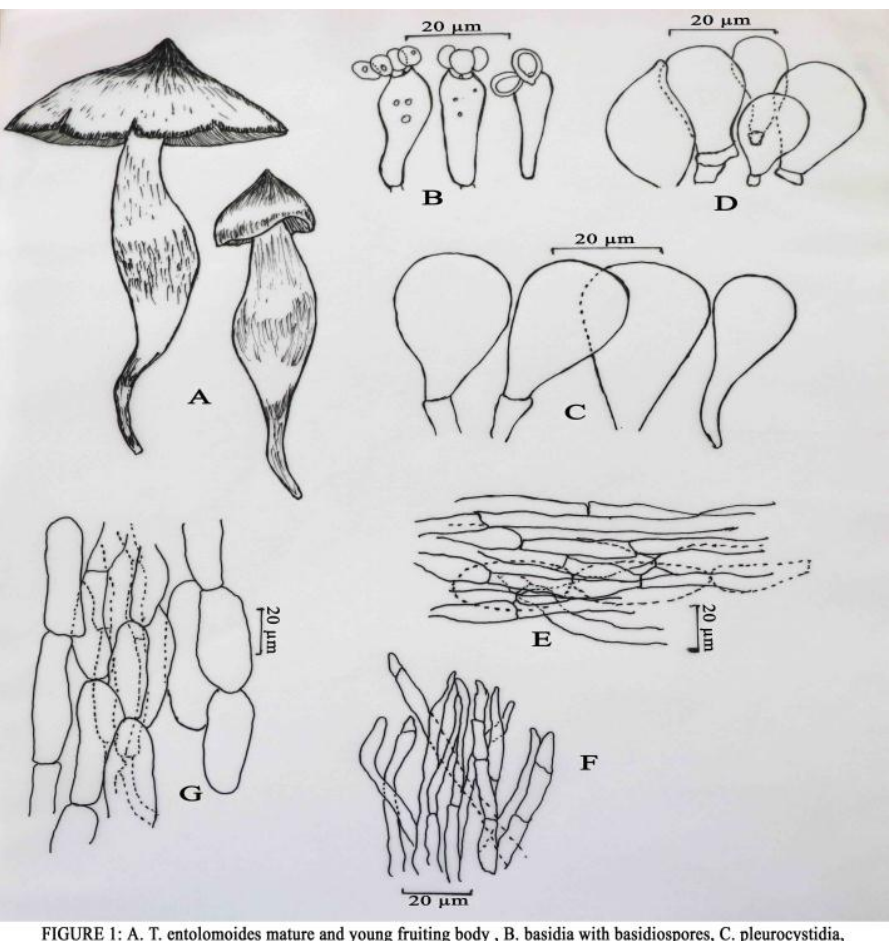

FIGURE 1: A. T. entolomoides mature and young fruiting body, B. basidia with basidiospores, C. pleurocystidia, D. cheilocystidia, E. hymenophoral trama hyphae, F. pileipellis hyphae, G. stipitipellis hyphae. 

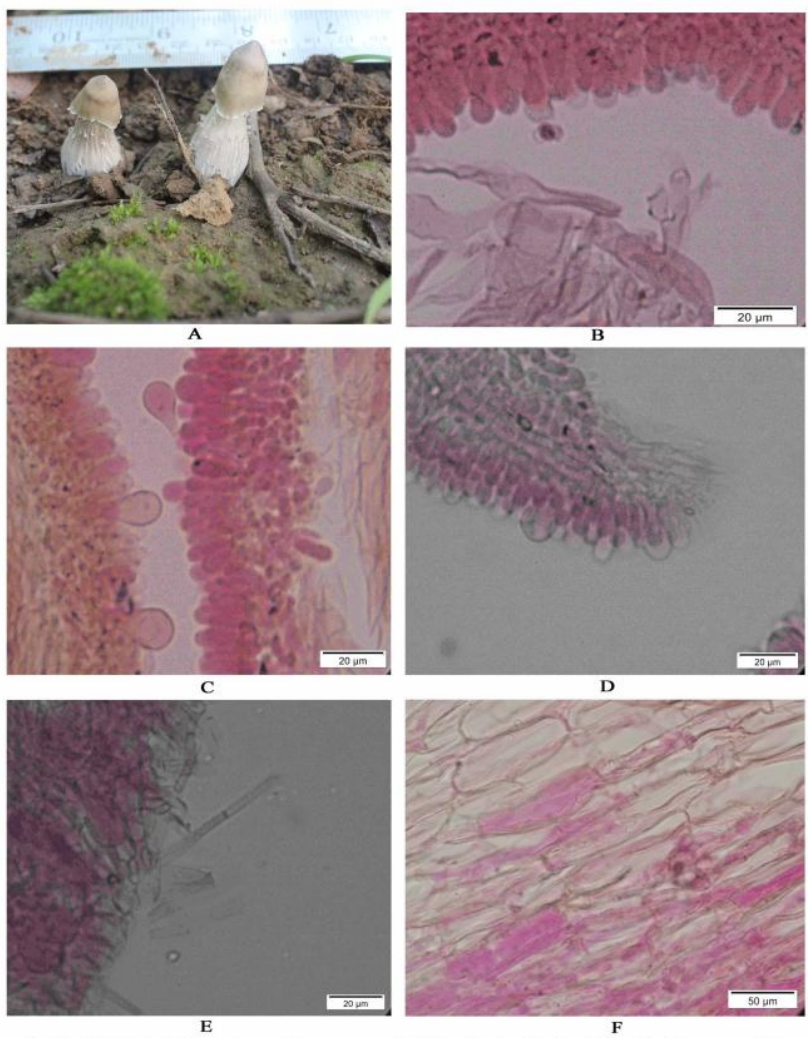

FIGURE 2: A. T. entolomoides young fruiting body, B. basidia, C. pleurocystidia,

D. cheilocystidia, E. pileipellis hyphae, F. stipitipellis hyphae.

\section{Phylogenetic Analyses}

The PCR product of BUMR07 results in $\sim 600$ bps in length. NCBI Blast confirms the sample as Termitomyces genus. ITS region sequences of Termitomyces entolomoides is not available in GenBank to confirm the species. The phylogentic analysis of the newly obtained sequence of BUMR07 and 19 NCBI downloaded sequence were clustered to form separate clades (Fig 3). BUMR07 is not clustered with any of the Termitomyces species, thus forming a separate clade $\mathrm{G}$ with $71 \%$ Bootstrap (BS) value. The GenBank based Asiatic Termitomyces sequences formed different clusters in separate clades A-F (Fig 3). Clade A with Termitomyces fuliginosus and Termitomyces eurhizus with $99 \%$ BS value. Clade B consists of Termitomyces microcarpus with $96 \%$ and $79 \%$ BS. Similarly, Clade C,D,E and $\mathrm{F}$ are separately clustered with Termitomyces clypeatus (74\%), Termitomyces intermedius (100\%), Termitomyces radicatus (99) and Termitomyces auranticus (100\%). Lyophyllum semitale and Lyophyllum decastes forming the outgroup. All the clustering are fully supported by more than $70 \%$ of $\mathrm{BS}$ value.

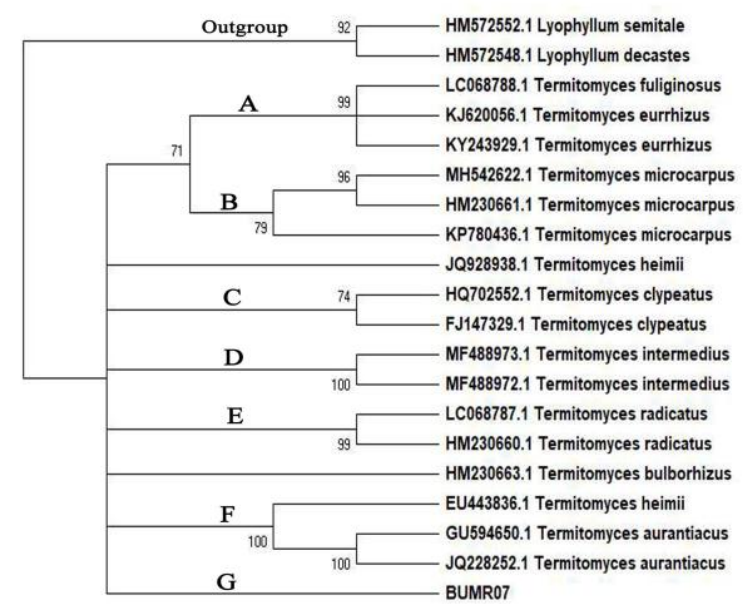

Figure 3. Molecular Phylogenetic analysis by Maximum Likelihood method

The evolutionary history was inferred by using the Maximum Likelihood method based on the Tamura-Nei model. The bootstrap consensus tree inferred from 1000 replicates is taken to represent the evolutionary history of the taxa analyzed. Branches corresponding to partitions reproduced in less than $70 \%$ bootstrap replicates are collapsed. The percentage of replicate trees in which the associated taxa clustered together in the bootstrap test (1000 replicates) are shown next to the branches. Initial tree(s) for the heuristic search were obtained automatically by applying Neighbor-Join and BioNJ algorithms to a matrix of pairwise distances estimated using the Maximum Composite Likelihood (MCL) approach, and then selecting the topology with superior log likelihood value. A discrete Gamma distribution was used to model evolutionary rate differences among sites $(5$ categories $(+G$, parameter $=0.9081)$ ). The analysis involved 20 nucleotide sequences. There were a total of 2233 positions in the final dataset. Evolutionary analyses were conducted in MEGA X.

The phylogenetic analyses showed the monophyletic tree from the pure Asiatic Termitomyces samples that originated from the same clade (Fig 3). Siddiquee et al., 2015 [2] reported the monophyly of pure Malaysian Termitomyces isolates and mixture of Asian and African Termitomyces. Frøslev et al., 2003 [6] revealed monophyly of Termitophilic fungi from separate and combined analyses of nLSU, mtSSU-rDNA and ITS data with BS value 99-100\%. Several studies used the ITS barcode with limited number of species or unidentified Termitomyces strains [21,22,23]. The above discussion suggested that the combined morphology and phylogeny characters support the identification of BUMR07 as Termitomyces entolomoides.

\section{CONCLUSION}

From the above study, it can be concluded that the Termitomyces species of Asian origin shares a common ancestor and are monophyletic. It is strongly suggested that the combined data of morphology and phylogeny characters are informative and useful equally for identification of a Termitomyces at a species level. The study promises potential to explore future possibility of cultivation technology in Termitomyces.

\section{ACKNOWLEDGEMENT}

The authors are thankful to Department of Agriculture, Govt. of Assam sponsored Mushroom Spawn Unit and DBT-GoI sponsored Technology Incubation Centre 
and Advanced level Biotech-Hub, Bodoland University for providing the laboratory facilities.

\section{REFERENCES}

[1] J. O. Kuja, H. I. Boga, V .Matiru, H. M Makonde, "Diversity, properties and ecological significance of the genus Termitomyces associated with fungus farming termites in Africa", International Journal of Micro Mycol , Vol 2, pp. 29-36, 2014.

[2] S. Siddiquee, K. Rovina, L. Naher, K. F. Rodrigues, M.A. Uzzaman, "Phylogenetic relationships of Termitomyces aurantiacus inferred from internal transcribed spacers DNA sequences", Advances in Bioscience and Biotechnology 6, no., 5, pp. 358-367, 2010.

[3] D.N. Pegler, M. Vanhaecke, "Termitomyces of Southeast Asia", Kew Bulletin, Vol 49, pp. 717-736,1994.

[4] N.C. Karun, K.R. Sridhar, "Occurrence and distribution of Termitomyces (Basidiomycota, Agaricales) in the Western Ghats and on the west coast of India", Czech Mycology, Vol 2, no., 65, pp. 233-254, 2003

[5] D. C. Mossebo, E. P. F. Essouman, M. C. Machouart, C. Gueidan. "Phylogenetic relationships, taxonomic revision and new taxa of Termitomyces (Lyophyllaceae, Basidiomycota) inferred from combined nLSU-and mtSSU-rDNA sequences." Phytotaxa, Vol 321, no., 1, pp. 71-102, 2017.

[6] T.G. Frøslev, D.K. Aanen, T. Laessoe, S. Rosendahl, "Phylogenetic relationships of Termitomyces and related taxa", Mycological research, Vol 107, pp. 1277-1286, 2003.

[7] R. Heim, "Termites et Champignons. Les champignons termitophiles d'Afrique Noire et d'Asie me'ridionale", E'ditions Boube'e, Paris, pp. 205, 1977.

[8] C.R. Woose, G.J, Olsen, "Archaebacterial phylogeny: perspectives on the urkingdoms", Syst Appl Microbiology, no., 7, pp. 167-177, 1986.

[9] T. J. White, T. Bruns, S. J. W. T. Lee, J. L. Taylor, “Amplification and direct sequencing of fungal ribosomal RNA genes for phylogenetics", PCR protocols: a guide to methods and applications, Vol 1, no., 18, pp. 315-322, 1990.

[10] G. Gogoi, V. Parkash, " A checklist of gilled mushrooms (Basidiomycota: Agaricomycetes) with diversity analysis in Hollongapar Gibbon Wildlife Sanctuary, Assam, India", Journal of Threatened Taxa,Vol 15, no., 7, pp. 8272-8287, 2015.

[11] M. Basumatary, M. Gogoi, "Uses of wild edible macro fungi by Bodo community of Kokrajhar district, Assam, India", An International Journal of Tropical Plant Research, Vol 3, pp.176181, 2016.

[12] M. Rava, R. Ali, H. Boro, S. Das, " Additional record of Termitomyces heimii, Kokrajhar, Assam, INDIA", Mushroom Research,Vol 26, pp.133-137, 2017.

[13] T.C. Sarma, I. Sarma, B.N. Patiri, "Wild edible mushrooms used by some ethnic tribes of Western Assam", The Bioscan, Vol 3, pp. 613-625, 2010

[14] K.D. Singha, K.D.K. Singha, "Occurrence of Termitomyces microcarpus mushroom in Assam", Advances in Plant Sciences, Vol 23, pp.439-440, 2010.

[15] A. Kornerup, J. H. Wanscher, "Methuen handbook of colour", 1963.

[16] J. Doyle, J. L. Doyle, “Genomic plant DNA preparation from fresh tissue-CTAB method", Phytochem Bull, Vol 11, no., 19, pp. 11$15,1987$.

[17] D. Darriba, G.L. Taboada, R . Doallo, D. Posada, "jModelTest 2: more models, new heuristics and parallel computing", Nature Methods, Vol 8, no., 9, pp.772, 2012.

[18] K. Tamura, G. Stecher, D. Peterson, "MEGA6: Molecular Evolutionary Genetics Analysis Version 6.0", The Society for
Molecular Biology and Evolution, Oxford University, Oxford, 2013.

[19] K.M. Leelavathy, L . Flower, C.P. Suja, "The genus Termitomyces in India", In: Kaul TN, Kapoor B.M., eds., Indian Mushroom Science II, New Delhi, pp. 402-407, 1983.

[20] C.K. Pradeep, K.B. Vrinda, "Some noteworthy agarics from Western Ghats of Kerala", Journal of Mycopathological Research, Vol 45, pp. 1-14, 2007.

[21] L.C. Rouland, , M. D. Ngor, A. Brauman, M. Neyra, "Phylogenetic Relationships in Termitomyces (family Agaricaceae) based on the nucleotide Sequence of ITS: A first approach to elucidate the Evolutionary History of the Symbiosis between Fungus-Growing Termites and their fungi", Molecular Phylogenetics and Evolution, Vol 3, no., 22, pp. 423-429, 2002.

[22] P. Sawhasan, J. Worapong, T. Vinijsanun, "Morphological and Molecular studies of selected Termitomyces species collected from 8 districts of Kanchanaburi Province, Thailand", Thai Journal of Agricultural Science, Vol 3, no., 44, pp.183-196, 2011.

[23] Y. Taprab, M. Ohkuma, T. Johjima, Y. Maeda, S. Moriya, T. Inoue, P. Suwanarit, N. Noparatnaraporn, T. Kudo, "Molecular Phylogeny of Symbiotic Basidiomycetes of Fungus-growing Termites in Thailand and Their Relationship with the Host", Bioscience, Biotechnology and Biochemistry, Vol 5, no., 65 , pp.1159-1163, 2002.

\section{AUTHORS PROFILE}

Mamoni Rava is a research scholar persuing $\mathrm{PhD}$ in Department of Biotechnology, Bodoland University Kokrajhar. She qualified CSIR NET-LS and SLET. She is a fellow of Rajiv Gandhi National Fellowship for ST students. She has 2 publications.

Raju Ali is a research scholar in the Department of Biotechnology ,Bodoland University Kokrajhar. He qualified CSIR NET-LS and SLET. He is a fellow of Maulana Azad National Fellowship for Minority students. He has 2 publications.

Sandeep Das is an Associate Professor in Department of Biotechnology, Bodoland University Kokrajhar. He has attained a $\mathrm{PhD}$ degree in Biotechnology from Gauhati University, India in 2012. He has more than 15 publications. He has represented in many scientific forms and has contributed immensely to science education. 